\title{
Corporate Purpose and Financial Performance
}

\section{Citation}

Gartenberg, Claudine, Andrea Prat, and George Serafeim. "Corporate Purpose and Financial Performance." Harvard Business School Working Paper, No. 17-023, September 2016.

\section{Permanent link}

http://nrs.harvard.edu/urn-3:HUL.InstRepos:30903237

\section{Terms of Use}

This article was downloaded from Harvard University's DASH repository, and is made available under the terms and conditions applicable to Open Access Policy Articles, as set forth at http:// nrs.harvard.edu/urn-3:HUL.InstRepos:dash.current.terms-of-use\#OAP

\section{Share Your Story}

The Harvard community has made this article openly available.

Please share how this access benefits you. Submit a story.

Accessibility 


\section{Corporate Purpose and Financial Performance}

Claudine Gartenberg Andrea Prat

George Serafeim

Working Paper 17-023 


\title{
Corporate Purpose and Financial Performance
}

\author{
Claudine Gartenberg
}

NYU Stern School of Business

\section{Andrea Prat}

Columbia University

George Serafeim

Harvard Business School

Working Paper 17-023 


\title{
Corporate Purpose and Financial Performance
}

\author{
Claudine Gartenberg \\ NYU Stern School of Business \\ Andrea Prat \\ Columbia University \\ George Serafeim \\ Harvard Business School \\ ***PRELIMINARY - PLEASE DO NOT CITE***
}

June 30, 2016

\begin{abstract}
We construct a measure of corporate purpose within a sample of US companies based on approximately 500,000 survey responses of worker perceptions about their employers. We find that this measure of purpose is not related to financial performance. However, high purpose firms come in two forms: firms that are characterized by high camaraderie between workers and firms that are characterized by high clarity from management. We document that firms exhibiting both high purpose and clarity have systematically higher future accounting and stock market performance, even after controlling for current performance, and that this relation is driven by the perceptions of middle management and professional staff rather than senior executives, hourly or commissioned workers. Taken together, these results suggest that firms with employees that maintain strong beliefs in the meaning of their work experience better performance.
\end{abstract}

\footnotetext{
* Claudine Gartenberg is an Assistant Professor of Management at NYU Stern School of Business; contact email: cgartenb@stern.nyu.edu. Andrea Prat is the Richard Paul Richman Professor of Business at Columbia Business School; contact email: ap3116@columbia.edu. George Serafeim is the Jakurski Family Associate Professor of Business Administration at Harvard Business School; contact email: gserafeim@hbs.edu. We thank the Great Place to Work Institute for giving us access to their full survey data. We are grateful to Alex Edmans, Rebeccan Henderson, Lamar Pierce and participants at NYU Stern Strategy Brownbag and the 2015 Israel Strategy Conference for many helpful comments. We are solely responsible for any errors in the manuscript.
} 


\section{Introduction}

Does purpose influence corporate performance? More than two decades ago, Bartlett and Ghoshal (1994) issued a call for strategy scholars to consider purpose as the essential precursor to effective strategic management. They argued for a shift from the "old doctrine of strategy, structure, and systems" to "a softer, more organic model built on the development of purpose, process, and people." The primary role of top management, in their view, is not to set strategy, but instead to instill a common sense of purpose (Bartlett and Ghoshal 1993). Since then, however, there has been little empirical progress (AMJ Editors 2014; Henderson and Van den Steen 2015), despite a five-fold increase in the public conversation about purpose between 1995 and 2016 (Oxford University and Ernst and Young, 2016). This gap also persists despite a resurgence of interest in both formal and "soft" organizational characteristics into studies of strategic outcomes (e.g., Kaplan and Henderson 2005; Nickerson and Zenger 2008; Argyres 2011; Helfat and Peteraf 2015; Felin, Foss and Ployhart 2015; Blader, Gartenberg, Henderson and Prat, 2015).

Perhaps one important reason for this limited research is the lack of measurement technology to evaluate purpose systematically across firms and years. We aim to overcome this measurement challenge and provide evidence on the relation between purpose and firm performance based on the most comprehensive data available to researchers, to our knowledge, on worker perceptions of their employers. As a result, we do not need to rely on reports from designated company representatives or advertised values on each company's website that have been shown to be 'cheap talk' and not predictive of corporate outcomes (Guiso, Sapienza, and Zingales 2015).

An organization's purpose is not a formal announcement, but depends on the employees believing in and acting to promote that purpose. Dennis Bakke, the CEO of AES, a global electric utility firm, highlighted the importance of this soft or implicit aspect by stating that it is only the company's "primary purpose - the real one, which isn't necessarily the one written in official documents or etched in wall plaques - [that] guides its actions and decisions." It is precisely this implicit aspect of purpose-that purpose is only effective insofar as it is actually adopted by employees within the firm - that creates the 
challenge for academics to study it meaningfully across firms and over time. Therefore, access to individual-level beliefs is a necessary precursor to creating measures of firm-level purpose.

Various definitions of purpose have been offered over time. One set of definitions explicitly focus on a social objective for the firm. For example, Bartlett and Ghoshal (1994) define purpose as "the statement of a company's moral response to its broadly defined responsibilities, not an amoral plan for exploiting commercial opportunity." Thakor and Quinn (2013) similarly define it as "something that is perceived as producing a social benefit over and above the tangible pecuniary payoff that is shared by the principal and the agent." Purpose, however, need not be explicitly pro-social. Oxford Dictionaries define purpose as "the reason for which something is done or created or for which something exists."1 Applying this general definition to a firm context, the Purposeful Company Report - written by a consortium of academics studying purpose in businesses - defines the purpose of a company as "its reason for being."2 Similarly, Henderson and Van den Steen (2015) write that purpose is "a concrete goal or objective for the firm that reaches beyond profit maximization."

In this paper, we adopt this broader view of corporate purpose, as the meaning of a firm's work beyond quantitative measures of financial performance. For example, a firm's purpose may be to fundamentally upend how an industry operates. Relatedly, one of the authors of this study, prior to joining academia, worked at a company whose purpose was "to change the way the world works." Dennis Bakke alludes to the purpose of AES as "meeting the world's need for safe, clean, reliable and economically priced electricity" (Bakke, 2003, pg. 30). In these examples, purpose is a meaning-rich articulation of the main business of the firm.

There is still limited evidence on the association between purpose and performance outcomes at the firm-level among publicly listed firms where profit maximization is often considered paramount (Stout 2012; Gomory and Sylla 2013; Strine 2014), while there has been now emerging evidence

\footnotetext{
${ }^{1}$ http://www.oxforddictionaries.com/us/definition/american english/purpose, accessed 3/15/16.

2 The Purposeful Company Interim Report, May 2016. http://www.biginnovationcentre.com/media/uploads/pdf/The\%20Purposeful\%20Company\%20Interim\%20Report.pd f, accessed 6/26/16.
} 
suggesting that companies with a more positive impact on environmental and social issues exhibit higher future financial performance, although these associations tend to be industry-specific (Khan, Serafeim and Yoon 2016). ${ }^{3}$ This limitation is particularly noteworthy because of the importance placed on purpose among practitioners, including CEOs, consultants and the press. The Brazilian cosmetics firm Natura and the Danish pharmaceutical firm Novo Nordisk, two of the most successful companies in terms of stock price performance in the last decade, have explicitly stated a purpose beyond profit maximization since their founding. ${ }^{4}$ Richard Branson, CEO of Virgin Group has said, "It's always been my objective to create businesses with a defined Purpose beyond just making money... our newest investment in OneWeb is also very much a Purpose-driven business, looking to create the world's largest constellation of satellites to bring connectivity and communications to billions who don't have access to the web." Similarly, Paul Polman, CEO of Unilever, has long supported the importance of purpose in business, "We have committed to help provide good hygiene, safe drinking water and better sanitation for the millions of people around the world who are still denied these basic human rights... It is about opportunity and aligning our purpose in business with this opportunity."

According to these business leaders, it is by focusing on instilling a strong sense of purpose within the firm that financial success is generated. In other words, the pursuit of purpose is facilitated by and enables the pursuit of business goals (Thakor and Quinn 2013). Purpose could relate to financial performance because it increases employee effort, customer loyalty and satisfaction, allows a firm to

\footnotetext{
${ }^{3}$ There is related work in management, psychology, and economics on the effects of pro-social incentives (see Cassar and Meier (2016) for a review). For example, Grant (2008a) finds that call center worker performance improves when they are more aware of the social purpose of their calls. Bode et al. (2008) finds that turnover decreases when employees engage in social initiatives with their firm. We consider this research relative to our findings in the discussion section.

${ }^{4}$ For Natura see: http://www.managementexchange.com/story/innovation-in-well-being ; for Novo Nordisk see http://www.managementexchange.com/story/how-novo-nordisk's-corporate-dna-drives-innovation. Both companies frequently top the list of sustainability indices provided by rating agencies such as the Dow Jones Sustainability index constructed by Robeco Sustainable Asset Management http://www.sustainability-indices.com/.

${ }^{5}$ How to manifest purpose in business: https://www.virgin.com/richard-branson/how-to-manifest-purpose-inbusiness

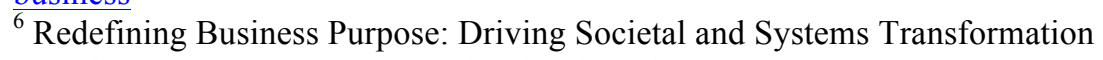
http://www.huffingtonpost.com/paul-polman/redefining-business-purpo b 6549956.html
} 
build relational contracts, or to decentralize, or because it shields an organization from short-term pressures. We consider each of these explanations in the context of our results.

However, these explanations about the benefits of purpose stand in contrast to a long-standing argument that a corporation's sole purpose is to maximize profits and as a result shareholder value (Friedman 1961). According to this view, the purpose of every (public) firm should be profit maximization, as managers are agents of shareholders, and any deviation is evidence of agency problems and impending financial underperformance (Jensen 2002). Consistent with that argument, scholars have argued for an increase in shareholder rights (Bebchuk 2013). Following this logic, any focus on corporate purpose that is not explicitly focused on shareholder returns represents, at best, a distraction for employees. Moreover, as Henderson and Van den Steen (2015) highlight, in order for a corporate purpose to be credible, the firm needs sometimes to make non-profit maximizing decisions. By this logic, therefore, a strong sense of purpose-aside from profit maximization-might lead to financial underperformance.

Given these divergent perspectives, our paper seeks to provide evidence about whether employee beliefs in a strong corporate purpose are associated with superior or inferior financial performance. Our evidence comes from a proprietary survey from the Great Place To Work (GPTW) Institute that covers employees across all hierarchical levels within hundreds of organizations that rate their employers in terms of a wide variety of organizational workplace variables.

The primary advantage of this dataset is that it allows us to construct measures across a diverse set of companies based on actual employee beliefs about their employer. Critically, a subset of the survey relates to purpose. We consider questions related to purpose as those that measure job meaning and employee pride ("My work has special meaning: this is not just a job"; "I feel good about the ways we contribute to the community"; "When I look at what we accomplish, I feel a sense of pride"; and "I'm proud to tell others I work here."). This is in line with research that operationalizes purpose as "when the direct outcome of the work fits your identity. You work because you value the work's impact" (Doshi and McGregor 2015). 
Moreover, the dataset gives us the opportunity to measure an array of employee beliefs about their employer (e.g. fairness, management quality) and relate them both to purpose and financial performance. This dataset also allows us to measure these beliefs at various job levels, from executives down to hourly workers, and report how beliefs at different levels relate to performance.

For this study, we focus on public companies and calculate measures of purpose for 456,666 employees within 429 firms and six years across a broad range of industries. We aggregate employees' responses to these questions, together with their other perceptions, and associate these aggregates to firm financial performance (i.e. operating Return on Assets (ROA) and Tobin's Q).

The first analysis yields a null result: we find that our measures of purpose exhibit no association with firm financial performance, either ROA or Tobin's Q. We then perform a factor analysis on the survey responses to identify whether purpose co-varies with other constructs within the data. From this analysis, we identify two groups of organizations with purpose. The first group, high purposecamaraderie organizations, includes organizations that score high on purpose and also on dimensions of workplace camaraderie (e.g. "This is a fun place to work"; "We are all in this together"; "There is a family or team feeling here"). The second group includes high Purpose-Clarity organizations that score high on purpose but also on dimensions of management clarity (e.g. "Management makes its expectations clear"; "Management has a clear view of where the organization is going and how to get there").

When we replace our aggregate measure of purpose with the factor measures capturing the two types of purpose organizations, we find that the high Purpose-Clarity organizations exhibit superior accounting and stock market performance. Our results hold after controlling for the full set of factors that score companies on the other measured dimensions of workplace practices, as well as our measure of overall level of employee satisfaction, so it is unlikely that a correlated omitted variable relating to employee beliefs is driving the association we document. In nearly all specifications, we also find a significant association even after controlling for the lagged level of the dependent variable, mitigating concerns about reverse causality. We also estimate regressions with firm fixed effects on a balanced 
sample of firms over time. We find a significant association between the Purpose-Clarity measure with both ROA and Tobin's Q suggesting that time-invariant firm-specific unobservable characteristics are also unlikely to explain the results.

Of course, lacking an instrument or a natural experiment, it remains a concern that an omitted variable not part of the GPTW survey could be the source of link association between our main variables of interest. To address this concern and also to explore our mechanism further, we next construct measures of firm-level purpose for employees at five levels of the organization (i.e., executives and senior managers, sales force, middle managers, salaried professionals, and hourly workers). Several additional findings emerge. First, we find systematic differences across levels of employees in their perception of purpose: the more senior the employee, the stronger is the perceived purpose of the organization. This is in line with practitioner claims that diffusing a sense of purpose in lower levels of the organization has not been successful in many firms (Graham et al., 2015; E\&Y 2016). Second, and most relevant to our study, it is solely the middle managers and salaried professionals that drive the relation between high "Purpose-Clarity" organizations and financial performance. We find no association for senior executives, sales or hourly workers. A reverse causality explanation-that strong performance, either current or anticipated, leads to a high sense of purpose among employees - would plausibly affect the senior executives and the sales force more strongly than the middle layer within the firm, since the compensation of the first two groups is most directly linked to firm performance. This is not what we find. Third, we use calendar time portfolio stock returns that are forward looking and do not suffer from reverse causality and find that a portfolio of high "Purpose-Clarity" firms earns significant positive risk-adjusted stock returns in the future, up to $7.6 \%$ annually, on par or greater than other studies of returns to intangible firm factors.

Our paper proceeds as follows. Section II presents the data and the sample. Section III presents our first analysis of purpose and firm performance. Section IV presents our factor analysis and association of factors to performance. Finally, section V provides a discussion and interpretation of our results. 


\section{Data and research design}

We construct our sample from GPTW survey data. The Great Places to Work ${ }^{\circledR}$ Institute administers Fortune Magazine's annual "100 Best Companies to Work For" list. Our study makes use of the raw data submitted by companies competing to be included on this list. This data have been previously used by Guiso, Sapienza and Zingales (2015) to understand corporate culture and its association with firm performance, as well as by Garrett, Hoitash and Prawitt (2014) to measure the relationship between employee trust and accounting quality. Edmans (2011) uses the outcome of the process-whether a company was chosen by the Institute to be included on the annual Fortune list - to assess whether companies included in the Top 100 Best Places to Work exhibit positive abnormal stock returns in the future.

To qualify for this list, companies must have more than 1,000 employees in the US for more than seven years. Approximately 400 public and private companies applied each year during our study period. The application process is lengthy and costly to administer; therefore, these large, established firms are a self-selected group that likely competes heavily for human capital (hence their desire to appear on the Fortune list). As such, these firms are likely leaders in employee-related management practices. We view this sample selection as somewhat decreasing the power of our test since it is unlikely that we will observe companies that have a very low sense of purpose. Moreover, the sample selection may limit the generalizability of our results if, for example, the firms that elect not to apply enact different human capital practices that have different performance implications. We discuss such limitations later in the paper, after we present our results.

Firms must submit two separate filings as part of the application: The Culture Audit Survey® (CAS) and the Trust Index $($ employee survey (TI). The CAS includes summary information on the company, including number and demographics of employees, geographic footprint of the company and information about compensation practices and corporate benefits. The TI is a randomized survey, stratified by employee job level, that includes 57 questions measuring various employees' beliefs about the workplace, such as management-employee relationship, workplace camaraderie, and pride in and 
meaning of the work. These responses span five job levels: hourly employees, sales (commission-based) workers, middle managers and supervisors, salaried professional and technical workers and executives and senior managers. ${ }^{7}$

Under our agreement with the Institute, we have access to all applications - both successful and unsuccessful - from 2006 to 2011. For our study, we focus on publicly-traded companies, which provides us with 429 firms and 917 firm-year observations. We use summary information from the CAS and TI survey data, which we aggregate up to the firm-year level. Altogether, the 917 firm-year observations include 456,666 survey responses from full time employees, with a median level of 498 responses per firm.

We construct a measure of purpose by aggregating four of the survey questions that relate directly to the concept of purpose. These questions are "My work has special meaning: this is "not just a job"", "When I look at what we accomplish, I feel a sense of pride;" "I feel good about the ways we contribute to the community," and "I'm proud to tell others I work here." We select those questions as they are the closest to research that operationalizes purpose as "when the direct outcome of the work fits your identity. You work because you value the work's impact" (Doshi and McGregor 2015). We equally-weight the four questions and take their average value to construct the index. In unreported analysis, we find very similar results when we use just one of the four measures iteratively or when we extract a common factor from the four based on factor analysis.

Table 1 shows the summary statistics for our sample. Unsurprisingly, given the application requirements, the sample firms are large, with an average of more than $\$ 50$ billion in assets and 15,000 employees. Average ROA is $10 \%$ with a standard deviation of $10 \%$. Average Tobin's Q is 1.96 with a standard deviation of 1.2. The mean firm has been incorporated for 59 years and has nearly 15,000 fulltime employees, consistent with our sample of larger, more established companies. The average score for our purpose measure is 4.3 with a standard deviation of 0.2 .

\footnotetext{
${ }^{7}$ While our data agreement precludes us from releasing the full set of questions from the survey, a public description of the survey instrument can be found here: http://www.greatplacetowork.net/our-approach/what-is-a-greatworkplace, accessed 6/25/16. Our four questions on purpose fall under the designated "Employee Pride" category.
} 
$<<$ Insert Table 1 about here $>>$

Figure 1 shows the average purpose measures by job level. Executives and senior managers score the highest, followed by middle managers and salespeople, then salaried professionals. Hourly employees score the lowest. This result is roughly consistent with the degree of responsibility by job level: executives have the most authority and concurrently have the strongest sense of purpose in their work, while hourly employees have the least and the weakest sense of purpose.

$<<$ Insert Figure 1 about here $>>$

Table 2 Panel A shows summary statistics by year. Two attributes of the data become apparent from this table. First, survey applications by public firms peak in 2006, with 207 companies applying, and reduce to 125 firms in 2010 . We speculate that this trend reflects economic conditions during the period: the GTPW application process is costly and likely fits into discretionary spending that is reduced during downturns. We later discuss how this selection effect may bias our analysis. Second, we can see that these firms are larger than the typical firm in the Compustat universe and consistently better performing, as measured by ROA. Once again, this result reflects the nature of the sample: these are large, wellperforming firms that are competing intensely on human capital.

Table 2 Panel B examines industry composition across the 12 Fama-French industries. The most highly represented industry is Business Equipment with 203 firm-year observations followed by Finance with 155 observations. First, while the industry distribution is broadly representative of the Compustat universe, there are some differences. In particular, Business Equipment and Retail are overrepresented, while Healthcare and Finance are underrepresented. While we cannot definitively state the reasons for these differences, we speculate that businesses will be overrepresented in industries in which the labor force pays special attention to this Fortune list. Second, showing that the statistics in Panel A are not 
driven by industry compositional effects, we see that firms in the GPTW sample are larger than the typical public firm in their industry and better performing.

$$
<<\text { Insert Table } 2 \text { about here }>>
$$

\section{Purpose and firm performance}

\section{Empirical specification}

We estimate the relation between our purpose measure and performance using an OLS model, clustering standard errors at the firm level to account for serial correlation within a firm over time. The model we estimate is:

Perf $_{\mathrm{it}}=\mathrm{a}+\mathrm{b}_{1} \times$ Purpose $_{\mathrm{it}}+\mathrm{b}_{2} \times$ ControlQ $\mathrm{b}_{3} \times$ HQState $_{\mathrm{i}}+\mathrm{b}_{4} \times$ Industry $_{\mathrm{i}}+\mathrm{b}_{5} \times$ Year $_{t}+\sum$ Controls $_{\mathrm{it}}$

where Perf ${ }_{\text {it }}$ is ROA, measured as EBIT (earnings before interest and taxes) over average total assets, or $\log$ of Tobin's Q for firm $i$ in year $t$. Tobin's Q is the ratio of market value of assets to book value of assets, where market value of assets is equal to market value of equity and total assets minus book value of equity. Purpose ${ }_{i t}$ represents our measure of purpose, the arithmetic average of an employee's answer to the four questions on the TI survey pertaining to purpose, aggregated up to the firm-year level. ControlQ is included to account for the "halo" effect: the overall happiness of the employee that may drive high scores to all questions. For this measure, we follow the approach taken by Guiso, Sapienza and Zingales (2015), and include the employee's answer to a TI survey question that is orthogonal to purpose but will still be influenced by overall happiness, "This is a physically safe place to work." HQState, Industry and Year represent the state of corporate headquarters, industry and year fixed effects. Controls include the natural logarithm of total assets, firm age, and employees.

Our setting does not provide an exogenous shock on purpose that is otherwise unrelated to firm performance; therefore, we are unable to establish causality. As such, we discuss our results using associative, rather than causal, language. To mitigate concerns over reverse causality and correlated omitted variables bias, we implement the following research design choices. First, we include the lagged 
value of the dependent variable, which controls for past factors that have influenced the performance of the firm and tend to have a persistent impact on a firm's performance (Wooldridge 2002). We next construct a balanced sample and introduce firm fixed effects to account for all time-invariant firm-specific unobservable characteristics. Third, we perform additional analyses that separate purpose according to the job level of the employees in the organization. This allows us to understand which, if any, job level is driving the association between purpose and performance and make inferences about the nature of the bias in our estimates. Last, we use calendar time portfolio stock returns that are forward looking and do not suffer from reverse causality. Specifically, we construct portfolios of firms that score high on cultural factors and investigate whether these portfolios have positive alphas after controlling for the Fama and French (1993) and Carhart (1997) factors. We estimate these regressions using time-series monthly data.

\section{Purpose and firm performance}

Table 3 shows our estimates of the association between purpose and firm performance. In Column (1), we use ROA as our firm performance variable. This specification includes our full set of controls, and year and industry fixed effects. We add our "halo" question in Column (2) to control for overall satisfaction at the firm, and we add a one-year lagged dependent variable in Column (3) to control for reverse causality. In none of these specifications is purpose positively related to ROA. In fact, in Columns (2) and (3), the point estimate is negative, and statistically significant in Column (3). Columns (4)-(6) repeat these analyses with log of Tobin's Q as our measure of firm performance. From this table we see no clear association between our measure of purpose and firm performance.

$<<$ Insert Table 3 about here $>>$

In Table 4, we decompose our aggregate measure of purpose within each firm and year into purpose by job levels within firm years. We do this further analysis in order to verify that our null finding at the firm level is not masking opposing effects by job level. We replace our firm-year measure of purpose with measures by job level within each firm and year. The results in this table show that none of 
the job level measures of purpose are related, either positively or negatively, to firm performance, supporting our null finding in Table 3.

$$
<<\text { Insert Table } 4 \text { about here }>>
$$

\section{Types of High Purpose Firms and Firm Performance}

There are several potential explanations for the null association between our measure of purpose and firm performance. ${ }^{8}$ In this section, we explore the following possibility: that purpose alone is not associated with performance, but purpose is bundled with other beliefs that, together, do matter for performance.

We perform an exploratory factor analysis on the raw survey questions to identify bundles of beliefs that co-vary with our purpose questions. We run the analysis at the employee level using all individual survey responses for all full time employees of all for-profit firms (both public and private). ${ }^{9}$ We include 53 of the 57 questions, excluding four questions that we considered to be outcome measures of overall job satisfaction and employee engagement. The factor analysis yields four factors that seem to explain most of the variation. ${ }^{10}$

We then apply a varimax rotation on our factors to orthogonalize, to the extent possible, our factor measures (Kaiser, 1958; Kim and Mueller, 1978). The rotation of the factor axes maximizes the variance of the squared loadings of a factor on all the variables in a factor matrix. As a result, it distinguishes between the original variables by extracted factor. The rotation yields either large or small loadings on each survey question, which allows us to characterize each factor by the set of questions that received high factor loadings. To construct firm-year level measures we average the survey level factor scorings at the firm-year level.

\footnotetext{
${ }^{8}$ For example, our purpose measure may not capture "purpose" in a meaningful way or there may be measurement error arising from the survey administration that we cannot observe.

${ }^{9}$ The survey also includes non-profit organizations and government agencies, both of which we exclude from this analysis, along with part-time employees at for-profit firms.

${ }^{10}$ We use a scree test to determine the number of factors to extract (Velicer and Jackson, 1990; Costello and Osborne, 2005). Applying this test, we observe a clear reduction in the differences between eigenvalues of incremental factors by Factor 5 and therefore keep the first four factors. The difference in eigenvalues between Factors 4 and 5 is 0.111 versus 0.053 between Factors 5 and 6, and these differences thereafter remain stable or diminish only very gradually.
} 


\section{Factor descriptions}

We identify four factors that represent bundles of questions for which employees tend to answer in conjunction with each other. Our data agreement with the GPTW Institute precludes us from publishing the survey instrument in totality, so in this section, we describe the nature of the questions captured by each factor in as much detail as possible without violating our data agreement.

Factor 1, which we call Management, is dominated by questions on employee perceptions of management quality and management's relationship with the company's employees (it is left open whether management refers to an employee's direct supervisors or to firm-level management). These questions focus on whether the employee believes management is approachable, honest, apolitical, and capable. The two questions with the highest loadings on this factor are "Management's actions match its words" and "I can ask management any reasonable question and get a straight answer."

Factor 2, which we call Purpose-Camaraderie, includes our four purpose questions, listed in the introduction section, together with questions on the degree of camaraderie between employees in the workplace. The two items with the highest loadings on this factor question i) whether employees have fun at work and ii) whether they believe that there is a familial atmosphere among employees at work. The other questions included in this factor similarly focus on workplace collegiality.

Factor 3, which we call Fairness, focuses on whether employees believe that there is workplace discrimination based on standard protected employee classes and sexual orientation. The highest loadings are on questions such as "People here are treated fairly regardless of their sexual orientation."

Factor 4, which we call Purpose-Clarity, includes our four purpose questions together with questions that characterize a workplace where management provides significant clarity around direction, job responsibilities, and tools that can be used to achieve the desired outcomes. The two items related to clarity with the highest loadings on this factor are "Management has a clear view of where the organization is going and how to get there" and "Management makes its expectations clear." 


\section{Factors and Firm Performance}

Table 5 shows a univariate correlation matrix for the four survey factors aggregated up to the firms level, together with our other firm-year survey and financial measures. A couple of interesting observations emerge from these correlations. First, the correlation between the different factors is moderate and ranges between -0.31 to 0.39 , allowing us to include all four factors together in a multivariate regression. ${ }^{11}$ Second, our two purpose-related factors, Factor 2 Purpose-Camaraderie, and Factor 4, Purpose-Clarity, are only modestly correlated with each other $(0.16)$, indicating that they are capturing very different sets of worker beliefs. Third and related to this prior point, our purpose measure is most highly correlated with Factor 2, Purpose-Camaraderie, (0.85), and only moderately correlated with Factor 4, Purpose-Clarity, (0.44). This moderate correlation indicates that Purpose-Clarity does capture additional beliefs aside from solely a sense of purpose among employees. Lastly, the strength of beliefs in purpose is higher for younger firms, firms with lower leverage and fewer employees, and firms with higher Tobin's Q. This overall pattern is maintained across Factors 1, 2 and 3. In contrast, the correlations for Factor 4 are the opposite: Purpose-Clarity is higher for larger, more established firms.

$$
<\text { Insert Table } 5 \text { about here }>>
$$

Figure 2 shows the raw fit between the two purpose factors and ROA. The association between PurposeCamaraderie and ROA is zero to negative, while the association between Purpose-Clarity and ROA is strongly positive. While this association in the raw data is useful, it does not account for multiple confounding factors. We now turn, therefore to multivariate models.

$$
<<\text { Insert Figure } 2 \text { about here }>>
$$

In Table 6, we replace purpose with our four survey factors. Column (1) measures the association between our two purpose factors and ROA. As with Figure 2, we see that Purpose-Camaraderie has no significant association with ROA, while Purpose-Clarity is strongly positive. This association is economically significant: an increase from the bottom to top decile in Purpose-Clarity is associated with

\footnotetext{
${ }^{11}$ Note that the factors are less correlated at the individual survey level, the level that we performed the varimax rotation. The aggregation to the firm-year level introduced these moderate correlations between the factors.
} 
an increase in ROA of $3.89 \%$. In Column (2), we include the other two factors as controls and the association between Purpose-Clarity and ROA remains significant and similar in magnitude. In Column (3), we also include the lagged ROA as a dependent variable. In this specification, the association disappears, indicating potential reverse causality at this aggregated level. An alternative explanation is that the financial benefits of purpose can be communicated and captured in stock prices faster than they flow in accounting performance. Given that most of the financial accounting transactions that are recorded are backward looking, it seems plausible to expect that the financial benefits of purpose will be detected in longer leads of ROA if one controls for lagged ROA. However, in a subsequent analysis we separately estimate the effect of purpose on ROA by job level and find that our result remains economically and statistically significant, even after controlling for lagged ROA.

Columns (4)-(6) repeat this analysis using logged Tobin's Q as the performance variable. We continue to find no association between Purpose-Camaraderie and Tobin's Q and a strong, positive association with Purpose-Clarity. In this case, the association remains when we include lagged Tobin's Q as a control (Column 6). Although it is attenuated in this specification, the association is still strong: an increase from the bottom to top decile in Purpose-Clarity is associated with an increase of 0.072 in logged Tobin's Q.

\section{$<<$ Insert Table 6 about here $>>$}

Our full sample is a highly unbalanced panel: we observe two thirds of our firms only once or twice. This imbalance renders a fixed effects analysis challenging, particularly since participation in the survey is voluntary and likely related to firm performance. To explore within-firm effects, therefore, we next restrict our analysis to firms that have appeared for all 6 years in our panel, which yields a balanced subsample of 29 firms and 174 observations. We rerun our analysis of Table 6 on that restricted subsample. First, in an unreported analysis, we replicate Table 6 on that subsample using OLS and show that the point estimates and significance of this subsample is similar to the full sample. We next include firm fixed effects. Table 7 shows the results: the coefficient on Purpose-Clarity is consistently positive 
and statistically significant, even with lagged performance variables. This analysis provides support that our results are not driven by unobservable time-invariant firm characteristics.

$$
<<\text { Insert Table } 7 \text { about here }>>
$$

Analysis by Job Level

For the next analysis, we separate Purpose-Clarity by job level and investigate which job level is driving the association with firm performance. Table 8 shows the correlations between the job level measures of Purpose-Clarity with each other and the other survey measures. A few notable insights are apparent from this table. First, the strongest correlation between job levels occurs between middle managers and professional-technical worker beliefs $(0.61)$, while executives and senior managers are only moderately correlated with the other job levels. Second, the other purpose factor, Purpose-Camaraderie, remains weakly correlated with these job-level Purpose-Clarity measures, and the strongest correlation is with hourly workers $(0.17)$ and the weakest with middle managers $(0.02)$ and negatively with executives (0.13). This weak correlation is consistent with these two factors capturing fundamentally different work orientations, with Purpose-Camaraderie workplaces putting significant weight on an atmosphere of strong interpersonal camaraderie and Purpose-Clarity workplaces focusing on job effectiveness.

$$
<<\text { Insert Table } 8 \text { about here }>>
$$

Table 9 repeats the analysis of Table 6, replacing the aggregate measure of Purpose-Clarity with the measures by job level. We find that two job levels drive the positive association with firm performance: middle managers and professional/technical employees. Several interesting observations emerge from this result. First, not finding any results for senior executives or salespeople suggests that reverse causality is unlikely to explain our results. Second, as we explore in the discussion section, this result provides evidence of the importance of strong, credible beliefs held by mid-level employees, particularly in the meaning of their job and clarity in how to succeed.

$$
<<\text { Insert Table } 9 \text { about here }>>
$$




\section{Future Stock Returns}

Table 10 shows estimates from calendar time portfolios of an investment strategy that buys the stocks of firms scored each year at the top quintile of Purpose-clarity and holds the portfolio for one year at which point it is updated with the new ranking of firms. The portfolios are formed on the $1^{\text {st }}$ of January. Our objective here is not to show that this is an implementable trading strategy since investors do not have access to this information. Our objective is rather to understand whether the Purpose-Clarity measure can predict future stock returns, a finding that would mitigate concerns about reverse causality and provide some sense of the economic magnitude of the phenomenon.

Each month the returns of each firm in the portfolio are equal-weighted and aggregated thereby constructing a portfolio return. The time-series of 72 monthly stock returns is then regressed on risk premiums for the market, size, value, and momentum factors (Fama and French 1993; Carhart 1997). Column (1) uses the overall Purpose-Clarity measure. Columns (2) and (3) use the Purpose-Clarity measure for middle managers and professional stuff respectively. Across all specification we find a positive and significant alpha (i.e. abnormal stock return). The annualized abnormal returns are estimated at $6.9 \%, 7.6 \%$ and $5.9 \%$ across columns (1), (2) and (3) respectively. These are economically meaningful estimates. By way of comparison Edmans (2011) finds that the Fortune Best Companies Top 100 list that is derived from the overall GPTW data earns a $4 \%$ annualized stock return. It is also of the same magnitude of other studies of intangible drivers of firm success, such as $4.6 \%$ for high R\&D capital (Lev and Sougiannis, 1996), $6.1 \%$ for firms in the top quintile of R\&D flows (Chan et al, 2000) and $8.5 \%$ for firms with strong governance (Gompers, Ishii, and Metrick, 2003). Therefore, our results in Table 9 suggest that our measure has a higher predictive power than the overall GPTW dataset.

$$
<<\text { Insert Table } 11 \text { about here }>>
$$

\section{Discussion of Mechanisms}


Our analysis suggests that high Purpose-Clarity organizations exhibit higher financial performance in the future, and particularly when these beliefs are held in the middle ranks of the organization. There are multiple reasons that could give rise to these patterns. While our tests cannot fully discriminate between them, we now discuss how these alternatives are more or less compatible with the different analyses presented in this paper. Specifically, we focus in this section on explanations of the following fact pattern: 1) the combination of purpose and clarity is associated with performance, rather than purpose alone, and 2) only beliefs within the middle ranks of organizations drive the association. ${ }^{12}$

Our explanations fall into two categories: i) those that relate to employees and implementation and ii) those that focus on constituencies other than employees.

\section{Employees and implementation}

While purpose is often straightforward to articulate, it is challenging to implement in a meaningful way within organizations. Most companies produce internal and external statements of their purpose and vision; however, as Guiso, Sapienza and Zingales (2015) find, these statements are cheap talk and unrelated to performance. Reflecting this implementation problem, one survey found that, while $89 \%$ of senior executives believed that organizations with shared purpose have higher employee loyalty, only $37 \%$ believed that their own business model and operations were aligned with their company's purpose (E\&Y 2016). Furthermore, the translation of purpose is hardest to employees that appear to matter most. A number of studies have shown that the high-ability workers are those that are most interested in meaningful work (Bode et al. 2015, Burbano, 2016). However, executives report that the hardest areas to integrate purpose are those that focus on high-skill labor: talent management, performance incentives and leadership development (E\&Y 2016).

\footnotetext{
${ }^{12}$ Perhaps equally interesting are the null results in our study: specifically, the lack of association between performance and purpose alone, purpose and camaraderie and our two other factors: management quality and fairness. However, for space reasons, we limit our discussion above to explanation of our positive results.
} 
Given this challenge in implementation, we now consider a four candidate explanations for why the combination of a high sense of purpose and management clarity together solves the implementation problem.

\section{Relational contracts and trust}

One mechanism through which Purpose-Clarity could be associated with higher firm financial performance is that this factor allows the firm to build and sustain relational contracts that in turn enable the firm to achieve superior financial performance. Relational contracts arise because of the inability to write complete contracts in the workplace. In order for different parties to enter into a relational contract, a necessary condition is for each party entering the contract to believe that the other party will 'cooperate' rather than 'defect' in the future (Kreps 1990). Furthermore, there is growing evidence that these relational contracts do influence employee behavior. In one recent example, Blader et al., (2015) find evidence that changes in the relational contract between the firm and workers is associated with changes in worker productivity.

Purpose can then be considered as a mechanism through which all parties assign a high probability of cooperation in the future. This is in line with a "team-production" theory of corporate law where the need for different stakeholders to make firm-specific investments in the absence of complete contracts that reward these investments gives rise to the need for a corporate purpose that goes beyond shareholder value maximization (Blair and Stout 1999; Stout 2012).

However, our findings show that purpose alone is not sufficient. The purpose-clarity combination is consistent with the argument by Gibbons and Henderson (2012) that emphasizes the role of clarity in building and sustaining relational contracts. They emphasize that inability to clearly communicate expectations and roles in a workplace ex ante makes it less likely for different parties to enter into relational contracts. Our findings are consistent with the following underlying mechanism: this clarity enables the translation of purpose from an abstract idea to specific actions that employees have confidence will be recognized (and rewarded) by their superiors. In that sense, the combination of purpose and clarity together enables the formation of a relational contract between senior management, 
middle management and lower level employees that solves the implementation problem and, as a result, influences performance.

Moreover, our finding that mid-level employees drive the association between purpose and clarity and financial performance further supports this interpretation. Given the role of these employees in executing the strategy within the firm (Wooldridge et al. 2008; Huy 2011), they are situated in a position to enforce and honor relational contracts inside the organization.

\section{Complementarities in management practices}

Another means by which Purpose-Clarity may be associated with higher performance is that this combination signifies that a coherent bundle of management practices has been implemented within the organization to instill purpose. In a series of papers beginning with Bloom and Van Reenen (2007), Bloom, Van Reenen, Sadun and co-authors report large-sample evidence that management practices are associated with higher firm performance. However, as Milgrom and Roberts (1995) point out, management practices combine in non-simple ways that can influence their outcomes. Implementation of mutually inconsistent practices, even if each one in turn appears promising, can lead to negative outcomes.

Blader, Gartenberg and Prat (2016) provide one stark example of this proposition: they find that instilling a team-oriented culture among workers negatively interacts with publicly disclosing worker performance. While both practices are generally considered high performance management practices, they suggest that workers in the team-oriented cultures view public performance disclosure as undermining the culture by pitting workers against each other. Relatedly, Keller and Price (2011) find that different "archtypes" of firms are associated with different practice bundles, and that firms that take a generalized approach to adopting practices underperform those that adopt specific bundles that match their overall orientation.

In the case of this study, it could be that, a strong sense of clarity, together with purpose, reflects a state in which management has implemented a set of management practices are consistent with, rather 
than undermining of, the purpose of the firm. As such, employees not only believe that the organization has a strong purpose but also that it is operationally committed to its implementation.

\section{Decentralization}

Decentralized organizations have been shown to perform better under certain conditions (Aghion et al., 2014). In decentralized organizations, mid-level employees have more autonomy, which is generally associated with higher perceptions of empowerment. One possibility is that high empowerment in turn leads to higher levels of perceived purpose. In this case, combining decentralization with clear direction from management (clarity) could lead to better and more efficient decision-making and, as a result, to higher financial performance. Decentralization would be especially important for middle managers under this explanation as our results suggest.

We attempt to test this explanation by constructing a proxy for decentralization, adapting the approach of Guadalupe and Wulf (2010) for our context. We measure the span of senior control as the ratio of the number of middle managers to senior managers and executives. Using their logic, the larger this ratio, the more middle managers report to senior managers, which effectively decentralizes power down to the middle manager layer. However, in an untabulated analysis, we do not find association between this proxy and our Purpose-Clarity measure, nor are our results diminished when including this decentralization proxy in our analyses.

\section{Employee engagement}

Past research has documented that when employees feel a sense of meaning in their work, their performance increases (see Cassar and Meier (2016) for a recent review). For example, in mission-driven organizations, pro-socially motivated employees are likely to achieve high performance in the workplace (Grant and Sumanth 2009). Relatedly, pro-social motivation predicts higher worker performance in settings with clear public good goals, such as government work (Perry and Hondeghem 2008), firefighting (Grant 2008b), and nursing (Riggio and Taylor 2000). 
In our sample, however, of large publically listed firms where the pursuit of profitability is the dominant institutional logic, we find no association between financial performance and purpose as perceived by front-line employees where we would expect pro-social motivation to be an important factor of engagement. Similarly, it is not clear under this explanation why clarity is an important factor, absent appealing to other mechanisms, such as incomplete and relational contracting.

\section{Other constituencies}

Our second category of explanations focuses on constituencies that are not the general employees of the firm. Here, we consider three of these (non-exclusive) explanations: i) short-termism of outside investors, ii) customer loyalty and iii) CEO style.

\section{Short-termism}

In this explanation, purpose is a mechanism to mitigate short-term pressures on business and as a result reduce managerial myopia. Senior policymakers have argued that many corporations exhibit shorttermism, a tendency to take actions that maximize reported short-term earnings and stock prices at the expense of long-term corporate performance (e.g., Levitt 2000; Donaldson 2005). ${ }^{13}$ Prior studies have documented the sources of short-termism, such as capital market pressures and managerial monetary incentives (Brochet, Loumioti and Serafeim 2015), as well as the negative effects of short-termism on strategic orientation (Connelly et al. 2010) and future shareholder value (e.g., Bushee 1998; Bhojraj et al. 2009). Corporate purpose could mitigate such short-term pressures by signaling to investors the type of the organization and as a result creating a more long-term oriented investor base or by aligning incentives inside the organization.

We view short-termism as unlikely to explain our results. If short-termism were the mechanism, one would expect that the relation between purpose and performance be driven by senior executives, who are the actors that make the myopic decisions criticized in the literature (e.g. cutting research and

\footnotetext{
${ }^{13}$ We mostly use the term "short-termism" but also occasionally refer to it as "myopia," another commonly used word to describe excessive focus on the short term in the corporate world and capital markets.
} 
development and other long-term investments). However, we find that senior executives' beliefs about purpose are not related to financial performance.

\section{Customer loyalty and satisfaction}

A separate literature has proposed that purpose leads to higher customer satisfaction and loyalty when customers themselves care about the firm's purpose ( $\mathrm{Du}$, Bhattacharya, and Sen 2007). This would be especially true if the firm's purpose is pro-social (Du, Bhattacharya, and Sen 2007; Nielsen 2014; Hainmueller and Hiscox 2012).

However, in unreported analyses, we find that our results do not differ significantly across consumer-oriented and business-oriented companies. Given that the customer loyalty and satisfaction effect should be stronger in consumer segments of the economy, we consider this evidence that this mechanism is unlikely to explain the relation between purpose and performance. Moreover, it is not clear why workplace clarity is an important factor in this mechanism, nor the mid-level employee result.

\section{Unobservable CEO style}

A number of papers document that a number of CEO characteristics are correlated with firm performance (Bertrand and Schoar 2003; Bennedsen et al. 2007, Kaplan et al. 2012; Bandiera et al. 2016). Our data does not allow us to measure dimensions of CEO behavior that are unobservable to the researcher. If these characteristics influence both perceived purpose and financial performance then they could be correlated omitted variables in our research design. For example, Bandiera et al. (2016) show that especially in poorer countries CEOs of a coordinative type versus a micro-manager type are associated with better performance. If coordinative type CEOs are able to build an organization of strong purpose then CEO type is a correlated omitted variable. For this alternative to be true, these CEOs would also have to instill beliefs about management clarity within mid-level employees. We note that the opposite could be true too: purpose allowing a CEO to be of a coordinative type therefore purpose driving the relation between coordinative type and performance. Of course almost all papers suffer from such 
unobservable correlated omitted variables and the best we can do it to caution the reader for their presence in interpreting the results.

\section{Conclusion}

We view our paper as a first attempt to provide empirical evidence on the value relevance of corporate purpose. We develop a new measurement technology that could help us systematically study corporate purpose and relate it to other firm characteristics. We find that an overall measure of purpose is not related to financial performance. However, we uncover that high purpose firms come in different types. Our data reveal two types: high camaraderie and high clarity workplaces. We find that the latter exhibits superior future performance. This result cannot be explained by time-invariant firm-specific characteristics or by observable time-varying firm-specific characteristics. Moreover, it is unlikely to be caused simply by reverse causality as our measure is able to predict future stock returns. Interestingly, we find that the significant association between high purpose high clarity and financial performance is driven by the middle ranks of the organization.

Our study leaves many questions unanswered and opens up significant opportunities for future research. First, why is purpose/clarity such an important driver of performance for middle managers and professional staff? Second, how is purpose/clarity built and diffused inside an organization? Third, how does purpose/clarity assist in building relational contracts, decentralization, or employee engagement and productivity? Shedding light on the mechanisms would be an important step forward. 


\section{References}

Aghion, Philippe, Nicholas Bloom, Raffaella Sadun, and John Van Reenen. "Never Waste a Good Crisis? Growth and Decentralization in the Great Recession." Harvard Business School Working Paper (2014).

Argyres, Nicholas. "Using organizational economics to study organizational capability development and strategy." Organization Science 22, no. 5 (2011): 1138-1143.

Bakke, Dennis. Joy at Work: A Revolutionary Approach to Fun on the Job. Seattle, WA: PVG, 2005

Bandiera, Oriana, Stephen Hansen, Andrea Prat, and Rafaella Sadun. "CEO Behavior and Firm Performance." (2016).

Bartlett, Christopher A., Sumantra Ghoshal, and Schendel, Dan. "Beyond the M-form: Toward a Managerial Theory of the Firm." Strategic Management Journal 14, No. S2 (1993): 23-46.

Bazigos, M and Emily Caruso. "Why Frontline Workers are Disengaged." McKinsey Quarterly, March, 2016.

Bebchuk, Lucian A. "The Myth that Insulating Boards Serves Long-Term Value." Columbia Law Review 113, no. 6 (2013): 1637-694.

Bennedsen, Morten, Martin Junge, Jesper Kragh Jacobsen, Svend Torp Jespersen, and Kasper Meisner Nielsen. "Ownership Structure and Economic Performance of European Corporations." Copenhagen Business School Working Paper No 03-2007, 2007.

Bertrand, Marianne, and Antoinette Schoar. "Managing with style: The effect of managers on firm policies." The Quarterly Journal of Economics 118, no. 4 (2003): 1169-1208.

Bhojraj, Sanjeev, Paul Hribar, Marc Picconi, and John McInnis. "Making Sense of Cents: An Examination of Firms that Marginally Miss or Beat Analyst Forecasts." Journal of Finance 64, no. 5 (2009): 2361-2388.

Blair, Margaret M., and Lynn A. Stout. "A team production theory of corporate law." Virginia Law Review (1999): 247-328.

Blader, Steven, Claudine Madras Gartenberg, and Andrea Prat. "The contingent effect of management practices." CEPR Discussion Paper No. DP11057, (2016).

Blader, Steven, Claudine Gartenberg, Rebecca Henderson, and Andrea Prat. "The Real Effects of Relational Contracts." American Economic Review Papers and Proceedings 105, no. 5 (2015): 45256.

Bloom, Nicholas, and John Van Reenen. "Measuring and Explaining Management Practices Across Firms and Countries." The Quarterly Journal of Economics 122, no. 4 (2007): 1351-1408.

Bloom, Nicholas, Raffaella Sadun, and John Van Reenen. "The Organization of Firms Across Countries." The Quarterly Journal of Economics 127, no. 4 (2012): 1663-1705.

Brochet, Francois, Maria Loumioti, and George Serafeim. "Speaking of the short-term: disclosure horizon and managerial myopia." Review of Accounting Studies 20, no. 3 (2015): 1122-1163.

Bode, Christiane, Jasjit Singh, and Michelle Rogan. "Corporate social initiatives and employee retention." Organization Science 26, no. 6 (2015): 1702-1720.

Burbano, Vanessa C. "Social responsibility messages and worker wage requirements: Field experimental evidence from online labor marketplaces." Conditionally Accepted, Organization Science (2016).

Bushee, Brian J. "The influence of institutional investors on myopic R\&D investment behavior." The Accounting Review 73 no. 3 (1998): 305-333.

Carhart, Mark M. "On persistence in mutual fund performance." The Journal of Finance 52, no. 1 (1997): 57-82.

Cassar, Lea, and Meier, Stephan, "Non-Monetary Incentives and the Quest for Work Meaning," (2016).

Connelly, Brian L., Laszlo Tihanyi, S. Trevis Certo, and Michael A. Hitt. "Marching to the beat of different drummers: The influence of institutional owners on competitive actions." Academy of Management Journal 53, no. 4 (2010): 723-742

Costello, A. B. and Jason W. Osborne. "Exploratory Factor Analysis: Four recommendations for getting the most from your analysis." Pan-Pacific Management Review 12, no. 2 (2009): 131-46. 
Doshi, Neel, and Lindsay McGregor. Primed to Perform: How to Build the Highest Performing Cultures Through the Science of Total Motivation. HarperCollins, 2015.

$\mathrm{Du}$, Shuili, C. B. Bhattacharya, and Sankar Sen. "Convergence of interests-cultivating consumer trust through corporate social initiatives." Advances in Consumer Research 34 (2007): 687.

Du, Shuili, Chitrabhan B. Bhattacharya, and Sankar Sen. "Reaping relational rewards from corporate social responsibility: The role of competitive positioning." International Journal of Research in Marketing 24 no. 3 (2007): 224-241.

Edmans, Alex. "Does the stock market fully value intangibles? Employee satisfaction and equity prices." Journal of Financial Economics 101, no. 3 (2011): 621-640.

Fama, Eugene F., and Kenneth R. French. "Common risk factors in the returns on stocks and bonds." Journal of Financial Economics 33, no. 1 (1993): 3-56.

Felin, Teppo, Nicolai J. Foss, and Robert E. Ployhart. "The microfoundations movement in strategy and organization theory." The Academy of Management Annals 9, no. 1 (2015): 575-632.

Foss, Nicolai J. "Toward an Organizational Economics of Heterogeneous Capabilities." International Journal of the Economics of Business 21, no. 1 (2014): 15-19.

Friedman, Milton. "The lag in effect of monetary policy." The Journal of Political Economy (1961): 447466.

Graham, John, Campbell Harvey, Jillian Popadak and Shiva Rajgopal. "Corporate Culture: Evidence from the Field." Duke University Working Paper (2015).

Grant, Adam M. "The significance of task significance: Job performance effects, relational mechanisms, and boundary conditions." Journal of Applied Psychology 93, no. 1 (2008): 108.

Grant, Adam M. "Does intrinsic motivation fuel the prosocial fire? Motivational synergy in predicting persistence, performance, and productivity." Journal of Applied Psychology 93, no. 1 (2008): 48.

Garrett, Jace, Rani Hoitash, and Douglas F. Prawitt. "Trust and financial reporting quality." Journal of Accounting Research 52, no. 5 (2014): 1087-1125.

Ghoshal, Sumantra, and Christopher A. Bartlett. "Linking organizational context and managerial action: The dimensions of quality of management." Strategic Management Journal 15, no. S2 (1994): 91112.

Gibbons, Robert, and Rebecca Henderson. "Relational contracts and organizational capabilities." Organization Science 23, no. 5 (2012): 1350-1364.

Gomory, Ralph, and Richard Sylla. "The American Corporation." Daedalus 142, no. 2 (2013): 102-118.

Gompers, Paul A., Andrew Metrick, and Joy L. Ishii. "IRRC Governance Data IRRC--Corporate Governance and Directors Datasets." The Quarterly Journal of Economics 118 (2003): 1.

Grant, Adam M. "Does intrinsic motivation fuel the prosocial fire? Motivational synergy in predicting persistence, performance, and productivity." Journal of Applied Psychology 93, no. 1 (2008): 48.

Grant, Adam M., and John J. Sumanth. "Mission possible? The performance of prosocially motivated employees depends on manager trustworthiness." Journal of Applied Psychology 94, no. 4 (2009): 927.

Guiso, Luigi, Paola Sapienza, and Luigi Zingales. "The value of corporate culture." Journal of Financial Economics 117, no. 1 (2015): 60-76.

Hainmueller, Jens, and Michael J. Hiscox. "The socially conscious consumer? Field experimental tests of consumer support for fair labor standards." MIT Political Science Department Research Paper No. 2012-05 (2012).

Helfat, Constance E., and Margaret A. Peteraf. "Managerial cognitive capabilities and the microfoundations of dynamic capabilities." Strategic Management Journal 36, no. 6 (2015): 831-850.

Henderson, Rebecca, and Eric Van den Steen. "Why Do Firms Have "Purpose"? The Firm's Role as a Carrier of Identity and Reputation." The American Economic Review 105, no. 5 (2015): 326-330.

Huy, Quy Nguyen. "How middle managers' group-focus emotions and social identities influence strategy implementation." Strategic Management Journal 32, no. 13 (2011): 1387-1410.

Imbens, Guido M., and Jeffrey M. Wooldridge. "Recent developments in the econometrics of program evaluation." Journal of Economic Literature 47 no. 1 (2009): 5-86. 
Jensen, Michael C. "Value maximization, stakeholder theory, and the corporate objective function." Journal of Applied Corporate Finance 22, no. 1 (2010): 32-42.

Kaiser, Henry F. "The varimax criterion for analytic rotation in factor analysis."Psychometrika 23, no. 3 (1958): 187-200.

Kaplan, Sarah, and Rebecca Henderson. "Inertia and incentives: Bridging organizational economics and organizational theory." Organization Science 16, no. 5 (2005): 509-521.

Keller, Scott, and Colin Price. Beyond performance: How great organizations build ultimate competitive advantage. John Wiley \& Sons, 2011.

Khan, Mozaffar, George Serafeim, and Aaron Yoon. "Corporate Sustainability: First Evidence on Materiality." Accounting Review (forthcoming).

Kim, Jae-On, and Charles W. Mueller. Factor analysis: Statistical methods and practical issues. Vol. 14. Sage, 1978.

Kreps, David M. "Game theory and economic modelling." Oxford University Press, 1990: 359-364.

Lev, Baruch, and Theodore Sougiannis. "The capitalization, amortization, and value-relevance of R\&D." Journal of Accounting and Economics 21, no. 1 (1996): 107-138.

Milgrom, Paul, and John Roberts. "Complementarities and fit strategy, structure, and organizational change in manufacturing." Journal of Accounting and Economics 19, no. 2 (1995): 179-208.

Nickerson, Jack A., and Todd R. Zenger. "Envy, comparison costs, and the economic theory of the firm." Strategic Management Journal 29, no. 13 (2008): 1429-1449.

Perry, James L., and Annie Hondeghem. Motivation in public management: The call of public service. Oxford University Press, 2008.

Riggio, Ronald E., and Shelby J. Taylor. "Personality and communication skills as predictors of hospice nurse performance." Journal of Business and Psychology 15, no. 2 (2000): 351-359.

Stout, Lynn A. The shareholder value myth: How putting shareholders first harms investors, corporations, and the public. Berrett-Koehler Publishers, 2012.

Strine Jr, Leo E. "Can we do better by ordinary investors? A pragmatic reaction to the dueling ideological mythologists of corporate law." Columbia Law Review (2014): 449-502.

Thakor, Anjan V., and Robert E. Quinn. "The economics of higher purpose." ECGI-Finance Working Paper 395 (2013).

Ton, Zeynep. The good jobs strategy: How the smartest companies invest in employees to lower costs and boost profits. Houghton Mifflin Harcourt, 2014.

Velicer, Wayne F., and Douglas N. Jackson. "Component analysis versus common factor analysis: Some issues in selecting an appropriate procedure." Multivariate Behavioral Research 25, no. 1 (1990): 128.

Wooldridge, Jeffrey M. "Inverse probability weighted M-estimators for sample selection, attrition, and stratification." Portuguese Economic Journal 1, no. 2 (2002): 117-139.

Zhang, Yu, and Javier Gimeno. "Earnings pressure and competitive behavior: Evidence from the US electricity industry." Academy of Management Journal 53, no. 4 (2010): 743-768. 
Figure 1: Purpose by Job Level

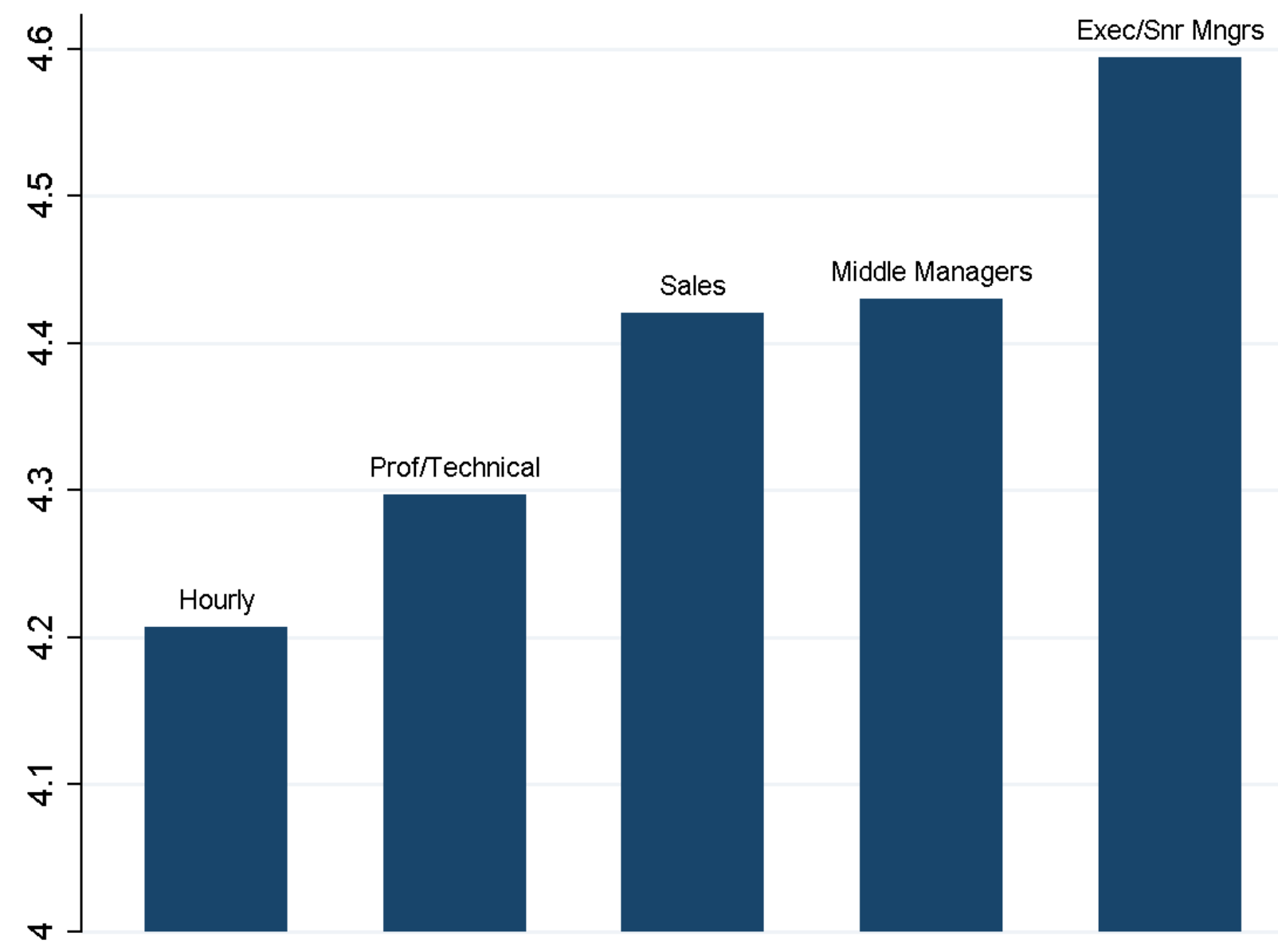


Figure 2: Purpose and Survey Factors and Firm Performance

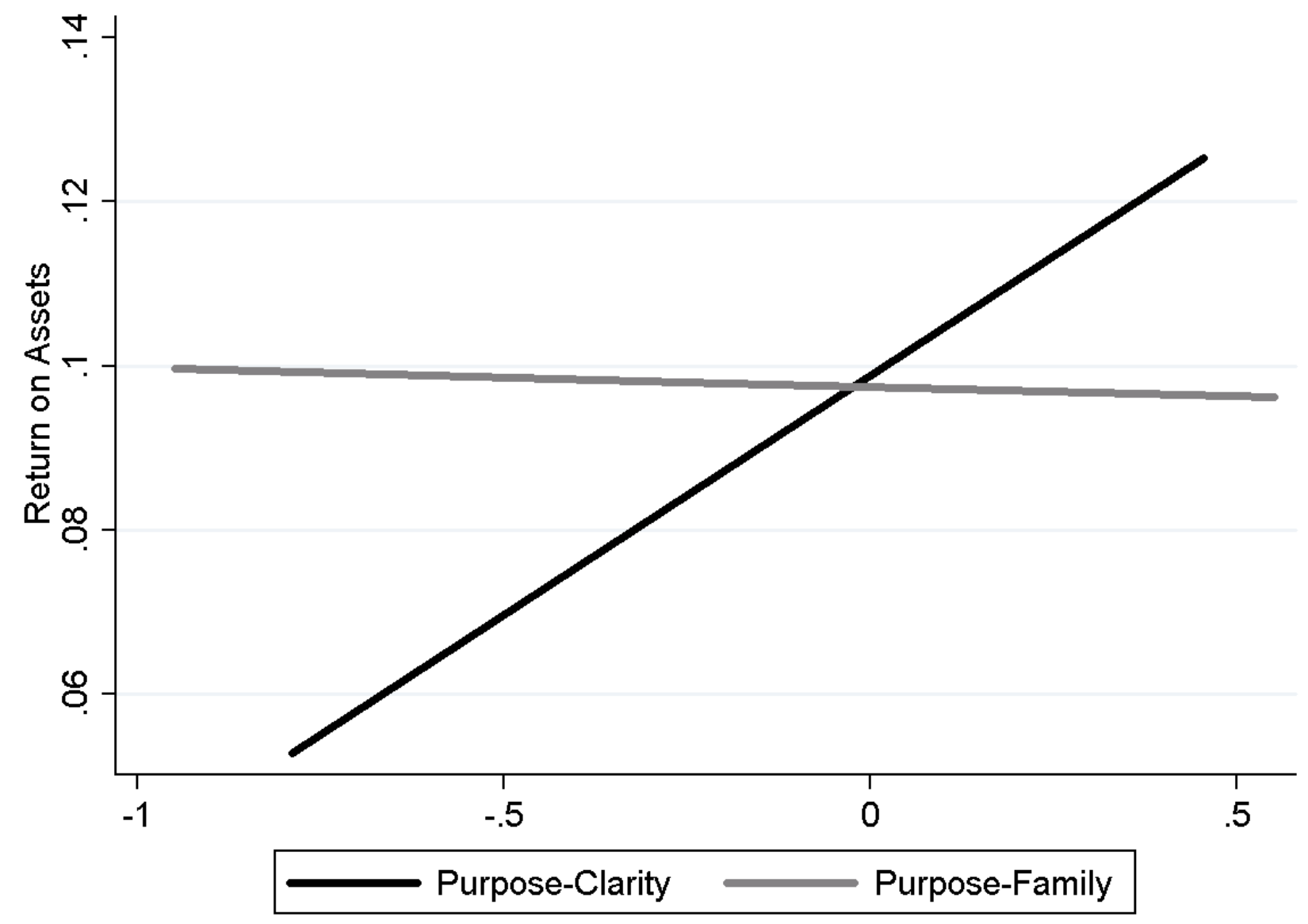


Table 1: Summary Statistics

\begin{tabular}{lrrrr}
\hline \hline Variable & Mean & Std. Dev. & Min & Max \\
\hline Financial information & & & & \\
Leverage ratio & 0.62 & 0.31 & 0.09 & 4.07 \\
Total assets & 50,996 & 193,772 & 30 & $3,221,972$ \\
Return on assets & 0.10 & 0.10 & -0.52 & 0.58 \\
Tobin's Q & 1.96 & 1.22 & 0.74 & 8.40 \\
Survey information & & & & \\
\# responses & 498 & 3,026 & 43 & 56,747 \\
Purpose index & 4.31 & 0.19 & 3.40 & 4.79 \\
Firm age & 59 & 46 & 2 & 228 \\
Full time employees & 14,915 & 24,000 & 584 & 285,609 \\
This is a physically safe & & & & \\
place to work & 4.66 & 0.19 & 3.66 & 4.96 \\
\hline
\end{tabular}

The table presents summary statistics for key variables. Leverage ratio is total debt over total assets. Firm age is the number of years since incorporation. Return on Assets is EBIT over average total assets. Tobin's $\mathrm{Q}$ is total assets plus market value of equity minus book value of equity at calendar year end over total assets. 
Table 2: Summary Statistics by Year and Industry

Panel A: By year

\begin{tabular}{rrrrrr}
\hline \hline Year & N & $\begin{array}{r}\text { Assets } \\
\text { (mean) }\end{array}$ & $\begin{array}{r}\text { Compustat } \\
\text { Assets } \\
\text { (mean) }\end{array}$ & ROA (med) & $\begin{array}{r}\text { Compustat } \\
\text { ROA (med) }\end{array}$ \\
\hline 2006 & 207 & 43,579 & 8,889 & 0.0967 & 0.0367 \\
2007 & 169 & 54,385 & 10,754 & 0.0965 & 0.0320 \\
2008 & 166 & 45,734 & 10,591 & 0.0826 & 0.0244 \\
2009 & 148 & 76,354 & 10,745 & 0.0890 & 0.0192 \\
2010 & 125 & 39,357 & 11,751 & 0.1017 & 0.0300 \\
2011 & 128 & 55469 & 12722 & 0.0962 & 0.0297 \\
\hline \hline
\end{tabular}

Panel B: By Industry

\begin{tabular}{rrrrrrrr}
\hline \hline Industry & N & $\begin{array}{r}\text { \% in } \\
\text { GPTW }\end{array}$ & $\begin{array}{r}\text { \% in } \\
\text { Compustat }\end{array}$ & $\begin{array}{r}\text { Assets } \\
\text { (mean) }\end{array}$ & $\begin{array}{r}\text { Compustat } \\
\text { Assets } \\
\text { (mean) }\end{array}$ & $\begin{array}{r}\text { ROA } \\
\text { (med) }\end{array}$ & $\begin{array}{r}\text { Compustat } \\
\text { ROA } \\
\text { (med) }\end{array}$ \\
\hline Consumer non-durables & 68 & $7 \%$ & $3 \%$ & 13,504 & 4,240 & 0.1278 & 0.0800 \\
Consumer durables & 15 & $2 \%$ & $2 \%$ & 4,550 & 10,843 & 0.1024 & 0.0430 \\
Manufacturi & 49 & $5 \%$ & $7 \%$ & 8,448 & 3,326 & 0.1101 & 0.0698 \\
Energy & 39 & $4 \%$ & $6 \%$ & 49,639 & 6,827 & 0.0639 & 0.0109 \\
Chemicals & 19 & $2 \%$ & $2 \%$ & 23,704 & 4,413 & 0.1478 & 0.0687 \\
Business equipment & 203 & $22 \%$ & $14 \%$ & 17,807 & 1,751 & 0.1075 & 0.0244 \\
Telecommunications & 19 & $2 \%$ & $3 \%$ & 65,671 & 13,842 & 0.0903 & 0.0639 \\
Utilities & 41 & $4 \%$ & $3 \%$ & 22,963 & 11,850 & 0.0676 & 0.0588 \\
Retail & 135 & $14 \%$ & $6 \%$ & 6,300 & 2,644 & 0.1083 & 0.0768 \\
Health & 26 & $3 \%$ & $9 \%$ & 18,975 & 1,678 & 0.1551 & -0.1908 \\
Finance & 155 & $16 \%$ & $32 \%$ & 228,116 & 39,305 & 0.0260 & 0.0194 \\
Other & 174 & $18 \%$ & $16 \%$ & 7,231 & 2,651 & 0.0786 & -0.0118 \\
\hline \hline
\end{tabular}

Panel A shows the frequency distribution of the sample observations across years. Panel B shows the frequency distribution of the sample observations across the 12 Fama-French industries. 
Table 3: Purpose and Firm Performance

\begin{tabular}{|c|c|c|c|c|c|c|}
\hline \multirow[t]{2}{*}{ Dependent variable: } & \multicolumn{3}{|c|}{ Return on Assets } & \multicolumn{3}{|c|}{ Log(Tobin's Q) } \\
\hline & $(1)$ & $(2)$ & $(3)$ & $(4)$ & $(5)$ & $(6)$ \\
\hline \multirow[t]{2}{*}{ Purpose } & 0.0073 & -0.0284 & $-0.0215 * *$ & $0.3214 * *$ & 0.1707 & 0.0408 \\
\hline & $(0.0239)$ & $(0.0291)$ & $(0.0103)$ & $(0.1376)$ & $(0.1736)$ & $(0.0613)$ \\
\hline \multirow[t]{2}{*}{ This is a physically safe place to work } & & $0.0775 * *$ & 0.0115 & & $0.3280 *$ & 0.0221 \\
\hline & & $(0.0332)$ & $(0.0127)$ & & $(0.1856)$ & $(0.0608)$ \\
\hline \multirow[t]{2}{*}{ Lagged Return on Assets } & & & $0.8308 * * *$ & & & \\
\hline & & & $(0.0340)$ & & & \\
\hline \multirow[t]{2}{*}{ Lagged Log(Tobin's Q) } & & & & & & $0.8345 * * *$ \\
\hline & & & & & & $(0.0228)$ \\
\hline \multirow[t]{2}{*}{ Constant } & 0.1973 & 0.0219 & -0.0090 & 0.2399 & -0.5055 & -0.2737 \\
\hline & $(0.1332)$ & $(0.1447)$ & $(0.0536)$ & $(0.7427)$ & $(0.7862)$ & $(0.3188)$ \\
\hline Year FE & $\mathrm{Y}$ & $\mathrm{Y}$ & $\mathrm{Y}$ & $\mathrm{Y}$ & $\mathrm{Y}$ & $\mathrm{Y}$ \\
\hline Industry FE & $\mathrm{Y}$ & $\mathrm{Y}$ & $\mathrm{Y}$ & $\mathrm{Y}$ & $\mathrm{Y}$ & $\mathrm{Y}$ \\
\hline Controls & $\mathrm{Y}$ & $\mathrm{Y}$ & $\mathrm{Y}$ & $\mathrm{Y}$ & $\mathrm{Y}$ & $\mathrm{Y}$ \\
\hline Observations & 917 & 917 & 917 & 917 & 917 & 917 \\
\hline Adjusted R-squared & 0.217 & 0.227 & 0.744 & 0.319 & 0.324 & 0.799 \\
\hline
\end{tabular}

OLS regressions. Purpose is the equally-weighted average of four questions related to purpose from the GPTW Institute survey. This is a physically safe place to work is a question from the GPTW Institute survey. Return on Assets is EBIT over average total assets. Tobin's Q is total assets plus market value of equity minus book value of equity at calendar year end over total assets. Standard errors are clustered at the firm-level and robust to heteroskedasticity. $* * *, * *$, signify statistical significant at the 1,5 , and $10 \%$ level respectively based on two-tailed tests. 
Table 4: Purpose by Job Level and Firm Performance

\begin{tabular}{|c|c|c|c|c|c|c|}
\hline \multirow[t]{2}{*}{ Dependent variable } & \multicolumn{3}{|c|}{ Return on Assets } & \multicolumn{3}{|c|}{ Log(Tobin's Q) } \\
\hline & $(1)$ & $(2)$ & (3) & $(4)$ & $(5)$ & $(6)$ \\
\hline \multirow[t]{2}{*}{ Purpose - Sales force } & 0.0021 & -0.0003 & -0.0016 & 0.0337 & 0.0227 & 0.0151 \\
\hline & $(0.0097)$ & $(0.0095)$ & $(0.0055)$ & $(0.0451)$ & $(0.0446)$ & $(0.0221)$ \\
\hline \multirow[t]{2}{*}{ Purpose - Middle Managers } & 0.0232 & 0.0178 & 0.0013 & 0.1793 & 0.1537 & 0.0365 \\
\hline & $(0.0237)$ & $(0.0230)$ & $(0.0101)$ & $(0.1170)$ & $(0.1148)$ & $(0.0601)$ \\
\hline \multirow[t]{2}{*}{ Purpose - Execs / Snr Managers } & -0.0036 & -0.0034 & -0.0029 & -0.0270 & -0.0253 & -0.0234 \\
\hline & $(0.0101)$ & $(0.0100)$ & $(0.0057)$ & $(0.0523)$ & $(0.0528)$ & $(0.0294)$ \\
\hline \multirow[t]{2}{*}{ Purpose - Prof / Technicals } & 0.0231 & 0.0189 & 0.0020 & 0.1471 & 0.1364 & -0.0087 \\
\hline & $(0.0176)$ & $(0.0174)$ & $(0.0079)$ & $(0.0970)$ & $(0.0956)$ & $(0.0453)$ \\
\hline \multirow[t]{2}{*}{ Purpose - Hourly workers } & -0.0266 & $-0.0442 * *$ & -0.0129 & 0.0265 & -0.0537 & 0.0625 \\
\hline & $(0.0199)$ & $(0.0213)$ & $(0.0092)$ & $(0.1023)$ & $(0.1086)$ & $(0.0543)$ \\
\hline \multirow[t]{2}{*}{ This is a physically safe place to work } & & $0.0745^{* *}$ & 0.0069 & & $0.3451 * *$ & -0.0072 \\
\hline & & $(0.0311)$ & $(0.0119)$ & & $(0.1667)$ & $(0.0587)$ \\
\hline \multirow[t]{2}{*}{ Lagged Return on Assets } & & & $0.8291 * * *$ & & & \\
\hline & & & $(0.0343)$ & & & \\
\hline \multirow[t]{2}{*}{ Lagged Log(Tobin's Q) } & & & & & & $0.8348 * * *$ \\
\hline & & & & & & $(0.0233)$ \\
\hline \multirow[t]{2}{*}{ Constant } & 0.1605 & -0.0490 & -0.0252 & 0.1500 & -0.8258 & -0.2603 \\
\hline & $(0.1320)$ & $(0.1465)$ & $(0.0590)$ & $(0.7314)$ & $(0.8144)$ & $(0.3502)$ \\
\hline Year FE & $\mathrm{Y}$ & $\mathrm{Y}$ & $\mathrm{Y}$ & $\mathrm{Y}$ & $\mathrm{Y}$ & $\mathrm{Y}$ \\
\hline Industry FE & $\mathrm{Y}$ & $\mathrm{Y}$ & $\mathrm{Y}$ & $\mathrm{Y}$ & $\mathrm{Y}$ & $\mathrm{Y}$ \\
\hline Controls & $\mathrm{Y}$ & $\mathrm{Y}$ & $\mathrm{Y}$ & $\mathrm{Y}$ & $\mathrm{Y}$ & $\mathrm{Y}$ \\
\hline Observations & 917 & 917 & 917 & 917 & 917 & 917 \\
\hline Adjusted R-squared & 0.219 & 0.229 & 0.743 & 0.320 & 0.326 & 0.799 \\
\hline
\end{tabular}

OLS regressions. Purpose is the equally-weighted average of four questions related to purpose from the GPTW Institute survey. It is calculated separately for each job level. This is a physically safe place to work is a question from the GPTW Institute survey. Return on Assets is EBIT over average total assets. Tobin's Q is total assets plus market value of equity minus book value of equity at calendar year end over total assets. Standard errors are clustered at the firm-level and robust to heteroskedasticity. $* * *, * *$ signify statistical significant at the 1,5 , and $10 \%$ level respectively based on two-tailed tests. 
Table 5: Univariate Correlations

\begin{tabular}{|c|c|c|c|c|c|c|c|c|c|c|c|c|c|}
\hline Variable & 1 & 1 & 2 & 3 & 4 & 5 & 6 & 7 & 8 & 9 & $\mathbf{0}$ & 11 & 12 \\
\hline 1 Purpose & 1 & & & & & & & & & & & & \\
\hline 2 This is a physically safe place to work & $0.54 *$ & 1 & & & & & & & & & & & \\
\hline 3 Management (Factor 1) & $0.66^{*}$ & $0.43^{*}$ & 1 & & & & & & & & & & \\
\hline 4 Purpose-Camaraderie (Factor 2) & $0.85 *$ & $0.39^{*}$ & $0.38^{*}$ & 1 & & & & & & & & & \\
\hline 5 Fairness (Factor 3) & $0.29 *$ & $0.70^{*}$ & $0.26^{*}$ & $0.19 *$ & 1 & & & & & & & & \\
\hline 6 Purpose-Clarity (Factor 4) & $0.44 *$ & $0.11^{*}$ & $0.17^{*}$ & $0.16^{*}$ & $-0.31 *$ & 1 & & & & & & & \\
\hline 7 Leverage & $-0.16^{*}$ & $-0.18 *$ & -0.04 & $-0.18^{*}$ & $-0.22 *$ & 0.01 & 1 & & & & & & \\
\hline 8 Log Assets & 0.04 & $0.14^{*}$ & -0.04 & $-0.14^{*}$ & $-0.11 *$ & $0.44^{*}$ & $0.14^{*}$ & 1 & & & & & \\
\hline 9Log age of firm & $-0.15^{*}$ & $-0.20 *$ & $-0.15^{*}$ & $-0.19^{*}$ & $-0.27 *$ & $0.15^{*}$ & $0.22 *$ & $0.25^{*}$ & 1 & & & & \\
\hline 10 Log full time employees & $-0.22 *$ & $-0.25^{*}$ & $-0.16^{*}$ & $-0.32 *$ & $-0.27 *$ & $0.18^{*}$ & $0.10^{*}$ & $0.56^{*}$ & $0.25^{*}$ & 1 & & & \\
\hline 11 Return on assets & 0.01 & 0.04 & -0.04 & 0.01 & 0.00 & $0.11^{*}$ & $-0.09 *$ & $-0.13^{*}$ & 0.02 & $0.08^{*}$ & 1 & & \\
\hline 12 Log Tobin's Q & $0.16^{*}$ & $0.20 *$ & 0.06 & $0.19 *$ & $0.19 *$ & 0.06 & $-0.13 *$ & $-0.26^{*}$ & $-0.14^{*}$ & $-0.14^{*}$ & $0.70^{*}$ & 1 & \\
\hline
\end{tabular}

The table presents univariate Pearson correlations. Purpose is the equally-weighted average of four questions related to purpose from the GPTW Institute survey. This is a physically safe place to work is a question from the GPTW Institute survey. Factors 1-4 are the outcomes of the factor analysis across 53 questions in the GPTW data. Leverage ratio is total debt over total assets. Firm age is the number of years since incorporation. Return on Assets is EBIT over average total assets. Tobin's $\mathrm{Q}$ is the market value of assets over the book value of assets. * represents statistical significance at the $5 \%$ level. 
Table 6: Survey Factors and Firm Performance

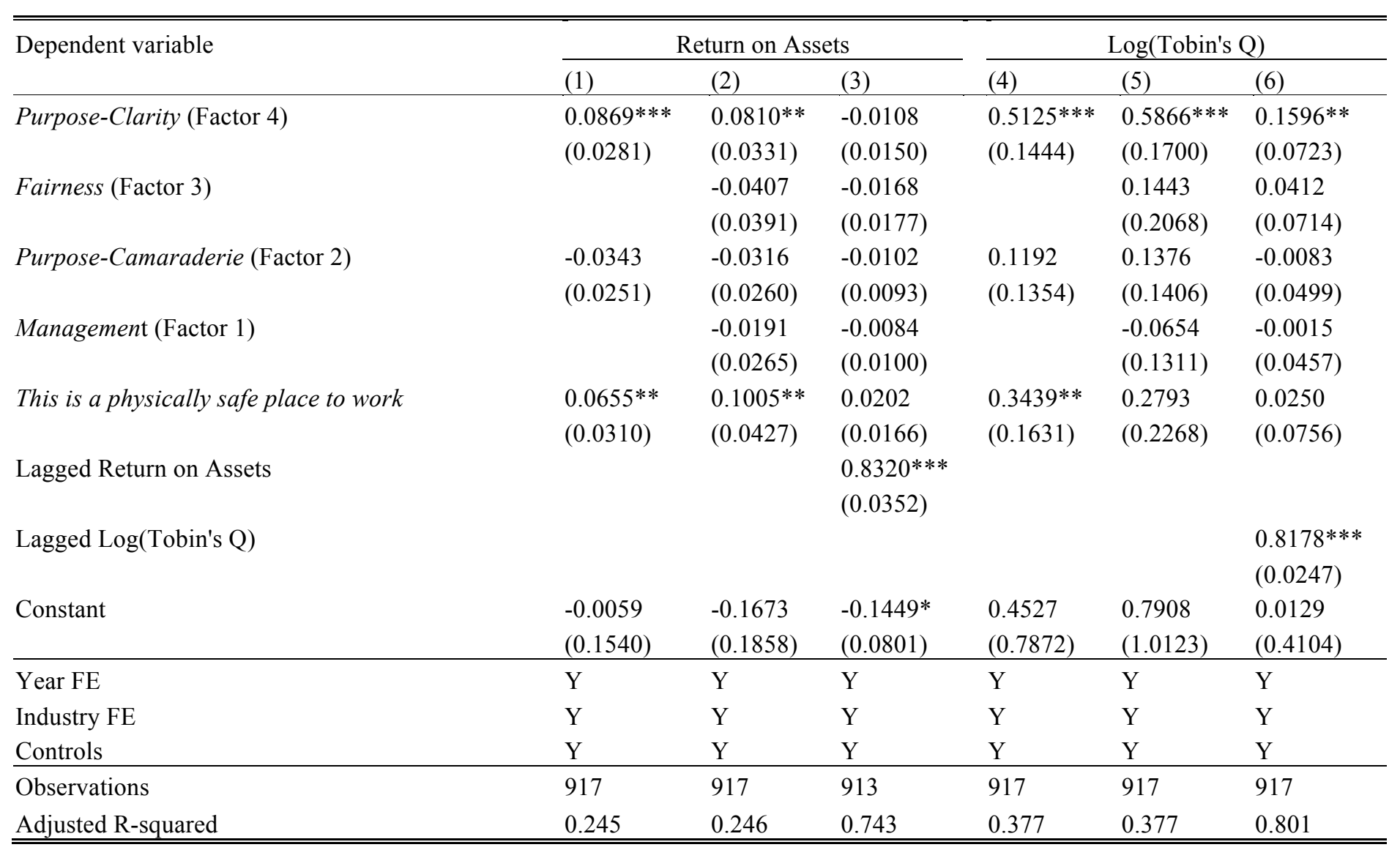

OLS regressions. Factors 1-4 are the outcomes of the factor analysis across 53 questions in the GPTW data. Leverage ratio is total debt over total assets. Firm age is the number of years since incorporation. This is a physically safe place to work is a question from the GPTW Institute survey. Return on Assets is EBIT over average total assets. Tobin's Q is total assets plus market value of equity minus book value of equity at calendar year end over total assets. Standard errors are clustered at the firm-level and robust to heteroskedasticity. ***,**,* signify statistical significant at the 1,5 , and $10 \%$ level respectively based on two-tailed tests. 
Table 7: Survey Factors and Firm Performance, Balanced Panel and Firm Fixed Effects

\begin{tabular}{|c|c|c|c|c|c|c|}
\hline \multirow[t]{2}{*}{ Dependent variable } & \multicolumn{3}{|c|}{ Return on Assets } & \multicolumn{3}{|c|}{ Log(Tobin's Q) } \\
\hline & $(1)$ & $(2)$ & $(3)$ & $(4)$ & $(5)$ & $(6)$ \\
\hline \multirow[t]{2}{*}{ Purpose-Clarity (Factor 4) } & $0.0980 * *$ & $0.1113 * *$ & $0.1248 * *$ & $0.5712 * * *$ & $0.6336 * * *$ & $0.6102 * * *$ \\
\hline & $(0.0404)$ & $(0.0524)$ & $(0.0541)$ & $(0.2000)$ & $(0.2021)$ & $(0.2110)$ \\
\hline \multirow[t]{2}{*}{ Fairness (Factor 3) } & & 0.0684 & 0.0877 & & 0.1095 & 0.0597 \\
\hline & & $(0.0875)$ & $(0.0892)$ & & $(0.2547)$ & $(0.2581)$ \\
\hline \multirow[t]{2}{*}{ Purpose-Camaraderie (Factor 2) } & 0.0099 & 0.0139 & 0.0065 & -0.1988 & -0.1507 & -0.1700 \\
\hline & $(0.0295)$ & $(0.0341)$ & $(0.0327)$ & $(0.1684)$ & $(0.1723)$ & $(0.1718)$ \\
\hline \multirow[t]{2}{*}{ Management (Factor 1) } & & 0.0153 & 0.0105 & & -0.0891 & -0.1053 \\
\hline & & $(0.0478)$ & $(0.0495)$ & & $(0.1668)$ & $(0.1599)$ \\
\hline \multirow[t]{2}{*}{ This is a physically safe place to work } & -0.0932 & -0.1624 & -0.1749 & -0.3237 & -0.3814 & -0.3490 \\
\hline & $(0.1126)$ & $(0.1614)$ & $(0.1639)$ & $(0.3159)$ & $(0.3808)$ & $(0.3854)$ \\
\hline \multirow[t]{2}{*}{ Lagged Return on Assets } & & & $0.1481 * *$ & & & \\
\hline & & & $(0.0667)$ & & & \\
\hline \multirow[t]{2}{*}{ Lagged Log(Tobin's Q) } & & & & & & 0.1149 \\
\hline & & & & & & $(0.1044)$ \\
\hline \multirow[t]{2}{*}{ Constant } & 0.5788 & 0.8964 & 0.9711 & $4.6873 *$ & $4.9560^{*}$ & $4.6129 *$ \\
\hline & $(0.6249)$ & $(0.8347)$ & $(0.8576)$ & $(2.3412)$ & $(2.5088)$ & $(2.3880)$ \\
\hline Year FE & $\mathrm{Y}$ & $\mathrm{Y}$ & $\mathrm{Y}$ & $\mathrm{Y}$ & $\mathrm{Y}$ & $\mathrm{Y}$ \\
\hline Firm FE & $\mathrm{Y}$ & $\mathrm{Y}$ & Y & $\mathrm{Y}$ & $\mathrm{Y}$ & Y \\
\hline Controls & $\mathrm{Y}$ & $\mathrm{Y}$ & $\mathrm{Y}$ & $\mathrm{Y}$ & $\mathrm{Y}$ & $\mathrm{Y}$ \\
\hline Observations & 170 & 170 & 170 & 170 & 170 & 170 \\
\hline Adjusted R-squared & 0.072 & 0.067 & 0.086 & 0.240 & 0.233 & 0.241 \\
\hline
\end{tabular}

Fixed effects regressions. Sample includes firms that appear in all 6 years of the survey in our sample. Factors 1-4 are the outcomes of the factor analysis across 53 questions in the GPTW data. Leverage ratio is total debt over total assets. Firm age is the number of years since incorporation. This is a physically safe place to work is a question from the GPTW Institute survey. Return on Assets is EBIT over average total assets. Tobin's Q is total assets plus market value of equity minus book value of equity at calendar year end over total assets. Standard errors are clustered at the firm-level and robust to heteroskedasticity. $* * * * *, *$ signify statistical significant at the 1,5 , and $10 \%$ level respectively based on two-tailed tests. 
Table 8: Survey Factors by Job Level Correlations

\begin{tabular}{|c|c|c|c|c|c|c|c|c|c|c|c|}
\hline Variable & & 1 & 2 & 3 & 4 & 5 & 6 & 7 & 8 & 9 & 10 \\
\hline 1 Purpose-Clarity (Factor 4) -- Sales & 1 & & & & & & & & & & \\
\hline 2 Purpose-Clarity (Factor 4) -- Hourly & $0.22 *$ & 1 & & & & & & & & & \\
\hline 3 Purpose-Clarity (Factor 4) -- Middle Mgr & $0.24 *$ & $0.56^{*}$ & 1 & & & & & & & & \\
\hline 4 Purpose-Clarity (Factor 4) -- Prof/Tech & $0.23 *$ & $0.49 *$ & $0.61^{*}$ & 1 & & & & & & & \\
\hline 5 Purpose-Clarity (Factor 4) -- Exec/Snr Mgr & $0.21 *$ & $0.32 *$ & $0.47 *$ & $0.40^{*}$ & 1 & & & & & & \\
\hline 6 Fairness (Factor 3) & -0.04 & $-0.22 *$ & $-0.28 *$ & $-0.30^{*}$ & $-0.15^{*}$ & 1 & & & & & \\
\hline 7 Purpose-Camaraderie (Factor 2) & 0.04 & $0.17 *$ & 0.02 & $0.10^{*}$ & $-0.13 *$ & $0.19 *$ & 1 & & & & \\
\hline $\mathbf{8}$ Management $($ Factor 1$)$ & $0.09 *$ & $0.14^{*}$ & $0.11 *$ & $0.12 *$ & -0.05 & $0.26^{*}$ & $0.38 *$ & 1 & & & \\
\hline 9 Purpose & $0.16^{*}$ & $0.37^{*}$ & $0.27 *$ & $0.30^{*}$ & 0.05 & $0.29 *$ & $0.85^{*}$ & $0.66^{*}$ & 1 & & \\
\hline 10 This is a physically safe place to work & $0.13^{*}$ & $0.16^{*}$ & 0.05 & 0.02 & 0.02 & $0.70 *$ & $0.39 *$ & $0.43 *$ & $0.54^{*}$ & 1 & \\
\hline
\end{tabular}

The table presents univariate Pearson correlations. Purpose is the equally-weighted average of four questions related to purpose from the GPTW Institute survey. This is a physically safe place to work is a question from the GPTW Institute survey. Factors 1-4 are the outcomes of the factor analysis across 53 questions in the GPTW data. Factor 4 is calculated separately by job level. Leverage ratio is total debt over total assets. Firm age is the number of years since incorporation. Return on Assets is EBIT over average total assets. Tobin's Q is the market value of assets over the book value of assets. * represents statistical significance at the $5 \%$ level. 
Table 9: Survey Factors by Job Level and Firm Performance

\begin{tabular}{|c|c|c|c|c|c|c|}
\hline \multirow[t]{2}{*}{ Dependent variable } & \multicolumn{3}{|c|}{ Return on Assets } & \multicolumn{3}{|c|}{ Log(Tobin's Q) } \\
\hline & $(1)$ & $(2)$ & (3) & $(4)$ & $(5)$ & $(6)$ \\
\hline Purpose-Clarity (Factor 4) -- Sales & $\begin{array}{l}-0.0138 \\
(0.0091)\end{array}$ & $\begin{array}{l}-0.0133 \\
(0.0090)\end{array}$ & $\begin{array}{l}-0.0079 \\
(0.0049)\end{array}$ & $\begin{array}{l}0.0042 \\
(0.0410)\end{array}$ & $\begin{array}{l}0.0103 \\
(0.0411)\end{array}$ & $\begin{array}{l}0.0140 \\
(0.0206)\end{array}$ \\
\hline Purpose-Clarity (Factor 4) -- Hourly Employees & $\begin{array}{l}-0.0156 \\
(0.0236)\end{array}$ & $\begin{array}{l}-0.0187 \\
(0.0234)\end{array}$ & $\begin{array}{l}-0.0255^{* *} \\
(0.0128)\end{array}$ & $\begin{array}{l}-0.0017 \\
(0.1280)\end{array}$ & $\begin{array}{l}0.0285 \\
(0.1303)\end{array}$ & $\begin{array}{l}0.0670 \\
(0.0543)\end{array}$ \\
\hline Purpose-Clarity (Factor 4) -- Middle Managers & $\begin{array}{l}0.0454 * * \\
(0.0215)\end{array}$ & $\begin{array}{l}0.0466 * * \\
(0.0217)\end{array}$ & $\begin{array}{l}0.0118 \\
(0.0103)\end{array}$ & $\begin{array}{l}0.3480 * * * \\
(0.1164)\end{array}$ & $\begin{array}{l}0.3832 * * * \\
(0.1131)\end{array}$ & $\begin{array}{l}0.1200 * * \\
(0.0582)\end{array}$ \\
\hline Purpose-Clarity (Factor 4) -- Professionals & $\begin{array}{l}0.0659 * * * \\
(0.0187)\end{array}$ & $\begin{array}{l}0.0658 * * * \\
(0.0196)\end{array}$ & $\begin{array}{l}0.0255^{* *} \\
(0.0102)\end{array}$ & $\begin{array}{l}0.2347 * * \\
(0.0990)\end{array}$ & $\begin{array}{l}0.2627 * * * \\
(0.1006)\end{array}$ & $\begin{array}{l}0.0390 \\
(0.0460)\end{array}$ \\
\hline Purpose-Clarity (Factor 4) -- Executives & $\begin{array}{l}0.0154 \\
(0.0118)\end{array}$ & $\begin{array}{l}0.0150 \\
(0.0119)\end{array}$ & $\begin{array}{l}-0.0044 \\
(0.0071)\end{array}$ & $\begin{array}{l}0.0094 \\
(0.0547)\end{array}$ & $\begin{array}{l}0.0054 \\
(0.0551)\end{array}$ & $\begin{array}{l}-0.0274 \\
(0.0318)\end{array}$ \\
\hline Fairness (Factor 3) & & $\begin{array}{l}-0.0340 \\
(0.0364)\end{array}$ & $\begin{array}{l}-0.0110 \\
(0.0173)\end{array}$ & & $\begin{array}{l}0.2036 \\
(0.2011)\end{array}$ & $\begin{array}{l}0.0755 \\
(0.0715)\end{array}$ \\
\hline Purpose-Camaraderie (Factor 2) & $\begin{array}{l}-0.0337 \\
(0.0250)\end{array}$ & $\begin{array}{l}-0.0299 \\
(0.0260)\end{array}$ & $\begin{array}{l}-0.0132 \\
(0.0097)\end{array}$ & $\begin{array}{l}0.1020 \\
(0.1397)\end{array}$ & $\begin{array}{l}0.1306 \\
(0.1450)\end{array}$ & $\begin{array}{l}-0.0088 \\
(0.0507)\end{array}$ \\
\hline Management (Factor 1) & & $\begin{array}{l}-0.0239 \\
(0.0257)\end{array}$ & $\begin{array}{l}-0.0128 \\
(0.0101)\end{array}$ & & $\begin{array}{l}-0.0910 \\
(0.1287)\end{array}$ & $\begin{array}{l}-0.0126 \\
(0.0455)\end{array}$ \\
\hline This is a physically safe place to work & $\begin{array}{l}0.0743 * * \\
(0.0310)\end{array}$ & $\begin{array}{l}0.1075 * * * \\
(0.0411)\end{array}$ & $\begin{array}{l}0.0247 \\
(0.0175)\end{array}$ & $\begin{array}{l}0.3283 * * \\
(0.1655)\end{array}$ & $\begin{array}{l}0.2385 \\
(0.2291)\end{array}$ & $\begin{array}{l}-0.0037 \\
(0.0771)\end{array}$ \\
\hline Lagged Return on Assets & & & $\begin{array}{l}0.8225 * * * \\
(0.0350)\end{array}$ & & & \\
\hline Lagged Log(Tobin's Q) & & & & & & $\begin{array}{l}0.8232 * * * \\
(0.0242)\end{array}$ \\
\hline Constant & $\begin{array}{l}-0.0171 \\
(0.1559)\end{array}$ & $\begin{array}{l}-0.1666 \\
(0.1803)\end{array}$ & $\begin{array}{l}-0.1501 * \\
(0.0857)\end{array}$ & $\begin{array}{l}0.5642 \\
(0.8125)\end{array}$ & $\begin{array}{l}1.0351 \\
(1.0280)\end{array}$ & $\begin{array}{l}0.1411 \\
(0.4233)\end{array}$ \\
\hline Year FE & $\mathrm{Y}$ & $\mathrm{Y}$ & $\mathrm{Y}$ & $\mathrm{Y}$ & $\mathrm{Y}$ & $\mathrm{Y}$ \\
\hline Industry FE & $\mathrm{Y}$ & $\mathrm{Y}$ & $\mathrm{Y}$ & $\mathrm{Y}$ & $\mathrm{Y}$ & $\mathrm{Y}$ \\
\hline Controls & $\mathrm{Y}$ & $\mathrm{Y}$ & $\mathrm{Y}$ & $\mathrm{Y}$ & $\mathrm{Y}$ & $\mathrm{Y}$ \\
\hline Observations & 917 & 917 & 917 & 917 & 917 & 917 \\
\hline Adjusted R-squared & 0.266 & 0.267 & 0.747 & 0.355 & 0.356 & 0.800 \\
\hline
\end{tabular}

OLS regressions. Factors 1-4 are the outcomes of the factor analysis across 53 questions in the GPTW data. Leverage ratio is total debt over total assets. Firm age is the number of years since incorporation. This is a physically safe place to work is a question from the GPTW Institute survey. Return on 
Assets is EBIT over average total assets. Tobin's Q is total assets plus market value of equity minus book value of equity at calendar year end over total assets. Standard errors are clustered at the firm-level and robust to heteroskedasticity. ***,**,* signify statistical significant at the 1,5 , and $10 \%$ level respectively based on two-tailed tests.

Table 10: Purpose and Future Stock Returns

\begin{tabular}{llll}
\hline \hline & & $\begin{array}{l}\text { High Purpose-Clarity: } \\
\text { Piddle Managers }\end{array}$ & $\begin{array}{l}\text { High Purpose-Clarity: } \\
\text { Prof/Tech } \\
(3)\end{array}$ \\
\hline Alpha & $\begin{array}{l}\text { High Purpose-Clarity } \\
(1)\end{array}$ & $0.0061^{* *}$ & $0.0048^{*}$ \\
& $0.0056^{*}$ & $(0.0029)$ & $(0.0026)$ \\
Market & $(0.0029)$ & $0.8406^{* * *}$ & $0.8288^{* * *}$ \\
& $0.8756^{* * * *}$ & $(0.1448)$ & $(0.1273)$ \\
SMB & $(0.1478)$ & $0.4543^{* * *}$ & $0.5007^{* * *}$ \\
& $0.4492^{* * *}$ & $(0.1447)$ & $(0.1237)$ \\
HML & $(0.1476)$ & 0.1405 & $0.1787 *$ \\
& 0.1657 & $(0.1378)$ & $(0.1016)$ \\
UMD & $(0.1324)$ & $-0.3444 * * *$ & $-0.3135^{* * *}$ \\
& $-0.3267 * * *$ & $(0.1058)$ & $(0.0902)$ \\
\hline Observations & $(0.1074)$ & 72 & 72 \\
Adjusted R-squared & 72 & 0.854 & 0.876 \\
\hline \hline
\end{tabular}

Table shows estimates from calendar time portfolios of an investment strategy that buys the stocks of firms scored each year at the top quintile of Purpose-Clarity and holds the portfolio for one year at which point it is updated with the new ranking of firms. The portfolios are formed on the 1st of January. Each month the returns of each firm in the portfolio are equal-weighted and aggregated thereby constructing a portfolio return. The time-series of 72 monthly stock returns is then regressed on risk premiums for the market, size (SMB), value (HML), and momentum (UMD) factors (Fama and French 1993; Carhart 1997). Column (1) uses the overall Purpose-Clarity measure. Columns (2) and (3) use the Purpose-Clarity measure for middle managers and professional stuff respectively. $* * *, * * *$ signify statistical significant at the 1,5 , and $10 \%$ level respectively based on two-tailed tests. 